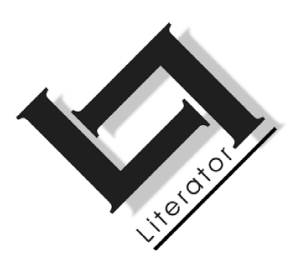

\title{
Skuil daar 'n verhaal in 'n liriese gedig? Nederlandstalige digters oor narratiwiteit in die poësie: Robert Anker, Tomas Lieske, Leonard Nolens, Willem van Toorn en Eva Gerlach
}

\author{
H.J.G. du Plooy \\ Skool vir Tale \\ Potchefstroomkampus \\ Noordwes-Universiteit \\ POTCHEFSTROOM \\ E-mail: heilna.duplooy@nwu.ac.za
}

\begin{abstract}
Is there a narrative hidden in a lyric poem? Dutch poets on narrativity in poetry: Robert Anker, Tomas Lieske, Leonard Nolens, Willem van Toorn en Eva Gerlach
\end{abstract}

This article is concerned with the views expressed by poets on narrativity in lyric poems. Contemporary poetic ideas and tendencies, such as the preference for longer poems, the use of sequences (sequential poetry) and cycles, are used as a point of departure and thus the argument is linked to historical issues. A motivation for the theoretical approach is provided because the article forms part of a larger project in which narrative structures and techniques in lyrical poetry are studied. The main part of the article is devoted to a discussion of the ideas of five poets, who write in Dutch, on the role and function of narrativity in their recent work. The discussion is based on extended interviews conducted with these poets. The article is concluded with an analysis and interpretation of a short cycle of poems by Eva Gerlach. 


\section{Opsomming}

\section{Skuil daar ' $n$ verhaal in ' $n$ liriese gedig? Nederlandstalige digters oor narratiwiteit in die poësie: Robert Anker, Tomas Lieske, Leonard Nolens, Willem van Toorn en Eva Gerlach}

In hierdie artikel word ondersoek ingestel na die siening van digters oor narratiwiteit in liriese gedigte. Die argument sluit dus aan by literêr-historiese aspekte, omdat dit gaan om poëtikale opvattings en om tendense in kontemporêre poësie, spesifiek die voorkeur vir langer gedigte, reekse en siklusse. Die artikel verskaf 'n teoretiese motivering vir die ondersoek en plaas die argument binne die groter raamwerk van die navorsing oor die rol en funksie van narratiewe aspekte en tegnieke in liriese poësie. Daarna word die sienings van vyf Nederlandstalige digters oor narratiwiteit in hulle eie werk bespreek na aanleiding van onderhoude wat met hulle gevoer is. Die artikel sluit af met 'n analise en interpretasie van 'n kort siklus gedigte van Eva Gerlach.

\section{Inleiding}

Hierdie artikel kom voort uit en sluit aan by navorsing oor die gebruik van narratiewe strukture en tegnieke in liriese poësie. ${ }^{1}$ In so 'n ondersoek moet daar rekenskap gegee word van die teoretiese uitgangspunte en metodologie en daar moet teksanalises gemaak word om die geldigheid van die benadering te bewys of te toets. Uiteindelik moet daar ook samevattende gevolgtrekkings gemaak word waaruit sowel die geldigheid van die teorie as die waarde van die teorie vir teksanalise kan blyk.

Hier word egter gefokus op nog 'n ander faset van die navorsing, naamlik die siening van digters self oor die plek, die rol en die waarde van narratiewe inhoud of tegnieke in hulle werk. Die argument sluit dus aan by inligting wat waarskynlik hoort by die literatuurgeskiedenis en wat te make het met die poëtikale opvattings van bepaalde digters.

Dit is uiteraard riskant om oor die verloop van literêre ontwikkelings gevolgtrekkings te maak as dit gaan om dieselfde tydperk waarbinne 'n mens jou bevind. Poëtikale opvattings van digters is ook nie die

1 Die artikel vorm deel van die projek, Vers en verhaal: narratiewe strukture en tegnieke in liriese poësie, en sluit dus aan by die teoretiese uitgangspunte in ander artikels in hierdie uitgawe van Literator. Daar verskyn in Stilet 22(3) 'n aantal artikels in Afrikaans oor Afrikaanse tekste wat ook deel vorm van die projek. 
enigste of selfs betroubaarste bron vir die indentifikasie van tendense nie. In oorgangsperiodes soos die huidige wat as post-postmodernisties beskryf word, geld die eis van omsigtigheid seker selfs sterker, omdat dit nog nie duidelik is watter eienskappe net by spesifieke individuele digters voorkom en watter werklik tot sterker tendense kan ontwikkel nie. Dit is egter wel boeiend om voorlopige waarnemings op te volg en te toets aan die werk van spesifieke digters en ook deur gesprekke met digters.

\section{Teoretiese agtergrond}

Die ondersoek van die gebruik van narratiewe strukture en tegnieke in liriese poësie, kom uit verskeie impulse, maar wat hier van besondere belang is, is die duidelike voorkoms van 'n narratiewe tendens in kontemporêre poësie en ook die toenemende hoeveelheid navorsing wat internasionaal gedoen word oor die konsekwensies van die vermenging van verskillende "modusse" in liriese tekste en die teoretiese implikasies daarvan.

\subsection{Reeksmatige poësie}

Daar is ' $n$ opvallende tendens in hedendaagse poësie dat digters dikwels gedigte in ruimer verbande plaas, dat hulle as 't ware ' $n$ "wyer doek" gebruik wat 'n agtergrond verskaf waarteen enkelgedigte geprojekteer word. Sowel in die Engelstalige, veral Amerikaanse poësie, as die Afrikaanse poësie en die Nederlandse poësie is daar duidelike voorbeelde wat daarop dui dat digters daaraan behoefte het om wyer of breër te werk en te dink as die grense van die enkelgedig. Baie digters skryf reekse gedigte of gedigsiklusse (wat vanselfsprekend nie in alle gevalle narratiewe eienskappe vertoon nie), maar daar is ook duidelik ' $\mathrm{n}$ voorkeur vir verhalende inhoud in bundels en in enkelgedigte (vgl. Marais, 2010; Naudé, 2010).

Een van die vorms van samehang wat in versreekse en -siklusse gevind kan word, is die aanwesigheid van meer of minder opvallende narratiewe lyne wat oor die grense van die enkelgedig heen kan strek. Dit word as 't ware opgebou deur gedigte met mekaar te laat skakel, sowel struktureel (deur 'n duidelike groepering aan te dui en gedigte in afdelings bymekaar te plaas, deur die ordening en volgorde in die bundel wat 'n bepaalde verloop en ontwikkeling suggereer, of deur die gedigte in herkenbare en benoemde siklusse of reekse te groepeer) as inhoudelik deur gedigte tematies by mekaar te laat aansluit. Die skakeling tussen gedigte in 'n afdeling, reeks of siklus berus dan dikwels op 'n narratiewe samehang, maar 'n enkele liriese gedig kan ook geanaliseer word deur spesifiek te gaan soek 
na onderliggende of verskuilde narratiewe inhoude of strukture, deur die teks as 't ware, in Monika Fludernik se terme, te "narrativiseer" (vgl. Abbott, 2009:320). Vanselfsprekend is narratiewe strukture en tegnieke in liriese poësie ook slegs een van die vorms van koherensie wat in die poësie waargeneem kan word, maar dit is inderdaad tans opvallend aanwesig (Toolan, 2009:44-45).

Hierdie artikel fokus op die werk en standpunte van vyf Nederlandstalige digters. Daar is ook in Afrikaans ' $n$ tradisie van langer of korter gedigte wat basies liries van aard is, maar wat tog ook verhalende aspekte vertoon. Voorbeelde wat genoem kan word, is die werk van D.J. Opperman met die bundel Komas uit 'n bamboesstok (1979) as hoogtepunt, verskeie bundels van Antjie Krog en die werk van H.J. Pieterse (Du Plooy, 2009:173-198). In Lady Anne (1989) sê Antjie Krog eksplisiet dat sy voortaan in terme van bundels eerder as in terme van enkelgedigte dink:

ek dink nie voorts in verse nie

maar bundels en die snode ys daarvandaan (Krog, 1989:15).

In Kleur kom nooit alleen nie (2000) gebruik Krog narratiewe op verskillende en uiteenlopende maniere (Du Plooy, 2010). Pieterse se bundel, Die burg van hertog Bloubaard, is 'n ander belangrike voorbeeld van 'n bundel waarin die bundel as geheel en reekse en siklusse binne die bundel op verskillende maniere 'n narratiewe samehang vertoon (Du Plooy, 2006:409-427). Ook in die werk van Engelstalige Suid-Afrikaanse digters is hierdie tendens opvallend duidelik aanwesig, byvoorbeeld in die bundel $A$ littoral zone (1991) van Douglas Livingstone (vgl. Kahl, 2010).

Frederick Feirstein, 'n Amerikaanse psigoanalitikus en digter, beskou die voorkeur vir gedigreekse en -siklussse as 'n vernuwingstrategie in die kontemporêre Amerikaanse poësie. Volgens Feirstein het die modernistiese poëtiese tradisie waarin soveel klem gelê is op poëtiese tegnieke en die uitbuiting van al die aspekte van poëtiese taalgebruik, uitgedien geraak en het hierdie "uitputting" van modernistiese konvensies die weg gebaan vir wat hy noem "expansive poetry" - liriese poësie wat nogtans 'n reeksagtige karakter vertoon:

[W] hen modernism in the hands of its imitators became dogma rather than adventure, and academic literary criticism became politicized, the techniques of rhyme and meter, like the genres of narrative and dramatic poetry, fell into disrepute. (Feirstein, 1998:255.) 
Hy verwys in sy argument spesifiek na die vermenging van vorms, genres en denkmodusse in kontemporêre poësie: "The sequential form, though lending itself best to the lyric and meditative poem, can encompass other genres as well." (Feirstein, 1998:265.) Hierdie uitspraak dui myns insiens daarop dat die versmelting of hibridisering van genres en style deel kan wees van die dinamiek van vernuwing in die poëtiese werkswyse en styl van 'n bepaalde periode of in die werk van 'n enkele digter.

\subsection{Teoretiese beskouings oor narratiwiteit in die poësie}

Daar is tans baie belangstelling in die narratiewe aspekte van liriese poësie. Dit blyk uit die toenemende aandag in die kontemporêre verhaalteorie aan die narratiewe vorms, strukture en tegnieke in die poësie (Hühn, 2005:139-158; Hühn \& Sommer, 2009:228-241; Dubrow, 2006:254-271; Hühn \& Kiefer, 2005). Daar word baie spesifiek aandag gegee aan liriese poësie waar die narratief in 'n subtiele en dikwels verskuilde vorm voorkom (Morgan, 2008:298-330; Sorensen Emery-Peck, 2008:331-358). ${ }^{2}$

Die voorkoms van 'n voorkeur vir "uitdyende poësie", wat wys op 'n behoefte aan 'n wyer perspektief, is waarskynlik een van die redes vir die toenemende belangstelling in die kontemporêre verhaalteorie vir die narratiewe aspekte van liriese poësie. Dit is egter ook waar dat die herlees van ouer gedigte duidelik toon dat die verskynsel wel algemeen in uiteenlopende poëtiese tradisies en in vroeër tydperke voorgekom het (vgl. Hühn \& Kiefer, 2005; Dubrow, 2006). Die aanwesigheid van narratiewe inhoude en strategieë in kontemporêre poësie is 'n eienskap van laatmodernistiese en postmodernistiese poësie, of minstens van die poësie van die laat twintigste en vroeë $21 \mathrm{e}$ eeue. Hierdie tendense, sowel as die kontemporêre teoretiese belangstelling daarin en navorsing daaroor, hou waarskynlik ook verband met die sogenaamde "narratiewe wending" wat steeds in soveel dissiplines en kommunikatiewe toepassings 'n prominente rol speel. ${ }^{3}$

2 Epiese poësie word gewoonlik as narratiewe tekste in poëtiese vorm bestudeer en is ' $n$ erkende en gerespekteerde tradisionele vorm van poësie ( $v g l$. Lind, 1998:323-361), maar in hierdie navorsing val die fokus juis op poësie wat primêr liries van aard is.

3 James Phelan (2005:85), redakteur van die gesaghebbende Amerikaanse tydskrif Narrative, verwys na hierdie verskynsel soos volg: "And the study of narrative across the disciplines, 'the narrative turn' in the academy, is still going 
Die benadering wat in hierdie artikel gevolg word, sluit aan by Dubrow (2006:254-271) se siening dat 'n mens nie moet bly steek in 'n ondersoek na en die aantoon van die verskille en onderskeide tussen liriese en verhalende tekste nie. 'n Mens moet eerder die voor die hand liggende verskille tussen die twee modusse ondersoek in die lig van die kompleksiteite van 'n spesifieke teks wat albei modusse gebruik en ook tematiseer.

I am arguing, then, that we need to calibrate our scales, devoting proportionately less attention to conflicts between lyric and narrative in order to recognize the frequency and variety of their cooperative interactions. (Dubrow, 2006:264.)

Hühn het verskeie studies die lig laat sien wat fokus op die narratiewe eienskappe van liriese poësie. Hy beredeneer en illustreer die moontlikhede wat die gebruik van die narratologie kan inhou vir die analise van poëtiese tekste met narratiewe eienskappe (Hühn, 2005; Hühn \& Kiefer, 2005). Hy beklemtoon, net soos Dubrow, dat wanneer die verhouding tussen narratiewe en liriese elemente en aspekte in poëtiese tekste ondersoek word, bepaalde eienskappe van die narratief in die analise van die poësie belangrik is. Hy stel dit egter ook baie duidelik dat daar 'n uniekheid in die narratiewe eienskappe van so 'n poëtiese teks is. Die analise van die verhouding van narratiewe eienskappe tot die "kerneienskappe" van die poësie moet verder vanselfsprekend geskied met inagneming van die historiese dimensie.

Phelan (2009:1) stem saam met McHale dat dit ' $n$ leemte in resente verhaalteorie of narratologie is dat daar so min aandag aan die narratiewe aspekte van die poësie gegee word. Hühn en Kiefer se uitgebreide studie, The narratological analysis of lyric poetry: studies in English poetry from the 16th to the 20th century (2005) en 'n hoofstuk, "Narration in poetry and drama", in die Handbook of narratology (Hühn \& Sommer, 2009) verskaf wel 'n goeie basis vir ander ondersoeke. McHale (2009:5) stel dit egter duidelik dat in sulke ondersoeke die poëtiese aard en kwaliteit nooit buite rekening gelaat mag word nie en hy stel voor dat segmentering, die manier waarop spasiëring (die wit/oop plekke en tipografie) en gebonde eenhede wat in die poësie gebruik word - onder meer strofes, versreëls, metriese versvoete en selfs woorde - as die kerneienskap van die poësie beskou word. Teenoor hierdie vorms van segmentering kan

strong and promises to continue generating important insights for years to come." 
daar in 'n narratief ook segmente onderskei word, naamlik gebeurtenisse, stemme, fokalisasies en temporele patrone. 'n Narratief in poëtiese vorm sal dus 'n unieke vorm vertoon, omdat twee soorte segmentering op mekaar inwerk en mekaar vooropstel en kontrasteer, sodat bykomende betekenisvolle strukture in 'n poëtiese narratief tot stand kom (McHale, 2009:18). McHale se siening sluit aan by beskouings van teoretici soos Bronzwaer (1993) en Lotman (1977) wat die spesifieke aard van die oorkodering deur middel van poëtiese taalgebruik as onontbeerlik vir poëtiese betekenis beskou. Waar McHale segmentering uitlig, sien Bronzwaer (1993:20-27), in aansluiting by die insigte van Lotman, ikonisiteit as die sentrale eienskap van die poësie. Dit gaan vir hom oor die oorkodering van tekste wat die referensiële werking van taal aanvul, deur die invoer van fonetiese, sintaktiese, metriese en metaforiese strukture en kodes, waardeur betekenis ikonies versterk en ondersteun word. Hoe die teoretici die klem ook al telkens verplaas (vgl. ook Hühn, 2005:142), almal beklemtoon dat die poëtiese eienskappe van 'n gedig steeds verreken moet word, al word daar op die narratiewe inhoud gefokus en al word die gedig narratologies ontleed. 4

Ter wille van die teoretiese legitimiteit van die navorsing waaroor dit hier gaan, moet gestel word dat daar 'n hele aantal ander teoretiese kwessies is wat by hierdie soort ondersoek aansluit en wat die teoretiese diskoers daaroor informeer. Dit word hier slegs genoem, aangesien dit buite die skopus van die artikel val:

- die verhouding tussen epiese poësie, die epos of verhalende gedig en liriese gedigte wat verhalende aspekte vertoon (Lind, 1998);

- die sogenaamde "lang gedig", wat soms verhalend, maar ook bespiegelend van aard kan wees (vgl. Willockx, 2010);

- die sterk bewustheid van die rol van narratiewe in die skepping en behoud van identiteit op alle vlakke van 'n samelewing, wat aansluit by die sogenaamde "narratiewe wending" (Bamberg, 2009); en

- genreteorie (Du Plooy, 2010).

$4 \quad$ Vir 'n uitvoerige uiteensetting van die ontwikkeling van die narratologie en 'n model vir 'n narratologiese analise, sien Du Plooy (1986:293-379). 
Vrae wat met reg gevra kan word en eventueel aandag sal moet kry as deel van 'n omvattende ondersoek na die verskynsel, is onder meer die volgende:

- Watter afleidings kan gemaak word in terme van kulturele en filosofiese ontwikkelings en literêr-teoretiese insigte oor die prominensie van narratiwiteit in kontemporêre liriese poësie?

- Wat is die poëtikale implikasies van die verskynsel vir 'n individuele digter, vir die poësie in 'n bepaalde taal, of selfs vir die poësie in verskillende tale?

- Hoe sou die verskynsel adekwaat in literêr-historiese sin beskryf kon word?

Terwyl al hierdie kwessies aan die orde gestel kan word, wil ek my in hierdie artikel rig op geselekteerde Nederlandstalige digters se uitsprake oor hulle eie werk. Dit is myns insiens tog 'n belangrike aspek van die ondersoek, naamlik om te kontroleer of daar 'n korrelasie is tussen die teoretiese redenasies, die literêr-historiese waarnemings, die pragmatiese aspekte van narratologiese lesings en die poëtikale sienings van digters oor hulle eie werk. ${ }^{5}$

\section{Vyf Nederlandstalige digters}

In November 2007 het die skrywer van hierdie artikel (Heilna du Plooy) en Bernard Odendaal6 onderhoude gevoer met vier Nederlandstalige digters, naamlik Robert Anker, Tomas Lieske, Willem van Toorn en Eva Gerlach. In 2008 het Du Plooy, tydens 'n verblyf as gasdosent in Antwerpen, ook met Leonard Nolens 'n onderhoud gevoer.

Volgens die uitsprake van hierdie vyf digters, wat vanselfsprekend geselekteer is op grond van hulle voorliefde vir "uitdyende poësie" en vanweë die prominensie van narratiewe inhoude, reekse en siklusse in hulle oeuvres, is die werking van 'n bykomende narratiewe stramien in hulle werk inderdaad belangrik.

$5 \quad$ In Stilet 22(3) verskyn twee artikels van die digters Danie Marais (2010:124143) en Charl Pierre Naudé (2010:11-123) waarin hulle hulle opvattings aangaande narratiwiteit in liriese gedigte uiteensit.

6 Bernard Odendaal is professor in die vakgroep Afrikaans en Nederlands, Duits en Frans aan die Universiteit van die Vrystaat in Bloemfontein. 


\subsection{Robert Anker}

Soos die meeste digters, is Robert Anker versigtig om oor sy eie werk tiperende uitsprake te maak. Hy gee wel toe dat die lang gedig Goede manieren (1989) "duidelijk narratief [is], om dat woord dan maar even over te nemen. Al was het natuurlijk niet lineair". Hy noem die gedig episodies, omdat die sewentien hoofstukke wat wel deels tematies by mekaar aansluit, los van mekaar staan en ook omdat veelvuldige personasies optree. Struktuur is vir hom baie belangrik en vanselfsprekend is alle vorms van struktuur nie verhalend nie. Wanneer daar egter sprake is van 'n reis of 'n roete, is daar volgens hom wel by implikasie 'n soort verhaal werksaam in die verse. Van die tiendelige versreeks "Senex en Safinur" in De Broekbewapperde mens, sê Anker (2002:39-50):

Het basisidee is dat deze Senex, de oude man, aan de rand van het leven terecht is gekomen - streepje kust dat hij nog bevat - en dat alles achter hem ligt. In contrast met zijn verzorgster, de Turkse verzorgster, die helemaal van het leven is nog, en ook nog aantrekkelijk voor hem is, nog wel. Blijkbaar had dat zoveel aspecten dat ik het tien keer heb gedaan. (Anker, 2007.)

Hieruit kan 'n mens duidelik aflei dat die veelfassettigheid van die problematiek van die onderwerp die digter daartoe bring om meerdere gedigte te skryf, om 'n versreeks te konstrueer om sodoende verskillende aspekte van die tema te kan betrek. Anker lê baie klem daarop dat hy in Goede manieren en in die meeste ander gedigte "ontsporende" sinne gebruik om die ontsporing van die hedendaagse lewe voor te stel, sodat die gedigte dan ikonies die lewensgevoel van 'n tydperk weergee. Hoewel dit dus gaan om 'n gebroke verhaal, 'n onlogiese en onsamehangende verhaal, is dit nodig om hierdie soort verhaal te herken as 'n ontspoorde of alternatiewe verhaal. Sodoende word dit duidelik wat die gedig wil beteken, naamlik dat die lewe van die hoofpersonasie onlogies en horisontaal is, net so gebroke soos die narratiewe struktuur van die gedig.

In "lemand van ons" (Anker, 2002:63-82) is elke vers egter 'n klein maar volledige sin; sinne wat wel van mekaar afhanklik is, wat deur mekaar aangevul word: "Maar eentje krijgt zijn kracht doordat het bij elkaar hoort." (Anker, 2007.) Dit impliseer weereens dat die veelkantigheid van die kontemporêre blik, oftewel van die postmodernistiese of post-postmodernistiese blik daartoe lei dat die digter meerdere gedigte nodig het om ' $n$ bepaalde onderwerp of aangeleentheid tot sy bevrediging poëties te ontgin. Dit impliseer ook dat die gedig seggingskrag ontleen aan die tekstuele konteks - van hoe en waar 
gedigte in 'n bundel staan en hoe gedigte tematies en op ander inhoudelike maniere aan mekaar verwant gemaak kan word om sodoende betekenis uit te brei. Hoewel die samehang en medewerksaamheid nie altyd narratief is nie, kan dit wel soms narratief van aard wees. Anker (2007) gebruik dikwels in die onderhoud woorde soos "volgorde" en "indeling" en sê dat daar 'n spesifieke indeling (struktuur) geskep word en dat dit bewus en nie naïef gedoen is nie. Uiteindelik stel hy ook dat Goede manieren met die personasie wat later daarin optree, naamlik Van Beek, subtiel aansluit by Nijhoff se Awater (deurdat in albei tekste die sentrale personasies se naam met water te make het) en dat Goede manieren dus in 'n mate tog as 'n hedendaagse gesekulariseerde peregrinasieverhaal7 beskou kan word (Anker, 2007).

\subsection{Tomas Lieske}

Tomas Lieske (2007) gee eksplisiet toe dat hy doelbewus narratiewe materiaal in sy gedigte benut, soos wat ook blyk uit die titel van sy bundel Stripping en andere sterke verhalen (2002). Hy sê:

Het is niet zozeer een keuze alswel dat ik dat soort poëzie interessanter vind. En leuker vind ... Ik dacht van als er een heel klein beetje een verhaal in zit, dan is dat toch misschien wat aantrekkelijker. (Lieske, 2007.)

Die effektiwiteit van kommunikasie met die leser speel dus vir hom 'n belangrike rol:

En ik probeer zowel de lezer tegemoet te komen door er een heel klein stukje verhaal in te brengen, omdat ik zelf dat ook wel aantrekkelijk vind als dat in andere poëzie gebeurt. Dat is een ding. En het andere is dat ik probeer in poëzie het wel over gevoelens te hebben, maar ik probeer duidelijk te maken dat het niet allereerst om mijn persoonlijke gevoelens gaat, want die zijn niet zo interessant voor de lezer. Maar het gaat om gevoelens die ik ook wel ken, maar die wat algemener zijn. (Lieske, 2007.)

Lieske gebruik dus die verhalende aspekte om juis 'n soort objektiwiteit in die verse te verkry, die teenoorgestelde van die tradisionele siening van die liriek as 'n hiperpersoonlike besinning in liriese taal.

7 Hoewel Anker versigtig was daarvoor het hy tog toegegee dat Goede manieren as 'n soort hedendaagse Elckerlijck beskou kan word wat juis die kontemporêre tydsgewrig se problematiek probeer weergee. 
Dit lyk asof hy daarop gesteld is om 'n "sterker" soort vers te skryf sonder dat dit 'n tipiese epiese vers word.

Dus, wat doen je dan, althans dat probeer ik, je neemt een personage of iets anders en je probeert van dat personage uit te vertellen ... Dus, er zijn voor mij ook vrij veel gedichten die een personage hebben, waarbij het personage spreekt ... maar daar is al, dit is in feiten al, een narratieve ontwikkeling ... want je bent bezig met het personage. Dus dan komt de volgende vraag al snel: Wat gebeurt er dan met zo iemand? (Lieske, 2007.)

Lieske werk eksplisiet met die narratiewe kategorieë van personasies en gebeure en beskou dit as 'n tegniek waarmee hy lesers beter kan boei. Hy wil dus die gedig trefkrag en samehang gee ter wille van 'n sterker appèl op die leser. Hy verduidelik ook dat dit vir hom nie om eie emosie gaan nie, maar om ervarings en emosies van personasies. Dit is dus 'n meer objektiewe soort poësie wat, hoewel dit liriese beskrywings bevat, nie persoonlik en meegevoerd is nie. Wat duidelik word, is dat die gedigte gebou is rondom klein verhale. Lieske skryf ook verhale en stel dit duidelik dat die twee soorte tekste totaal verskillend ontwikkel vanuit die skrywer se perspektief. Nogtans, waar 'n gedig soms wel 'n verhaal kan word, kan 'n verhaal nooit 'n gedig word nie. Hy verduidelik:

Poëzie ontstaat altijd met een taalkern, met een paar woorden. En die paar woorden geven op een of ander manier me het gevoel dat dat goed klinkt, dat dat over iets gaat wat ik soms nog niet eens kan benoemen, maar soms is het wel duidelijk. En dat is meer een gevoel dan een verhaal. En die kern probeer ik uit te breiden. (Lieske, 2007.)

Die gedigte bestaan dan dikwels net uit 'n verhaalkern met baie suggestie en oop plekke en die aantreklikheid van so 'n gedig lê vir hom juis in die gefragmenteerde aard van die (klein) verhaal.

\subsection{Leonard Nolens}

Leonard Nolens lê sterk klem op die ontwikkelingslyn in die gedagtegang in 'n gedig. Vir hom is selfs die samehangende argument in 'n filosofiese geskrif iets wat as 'n narratief beskou kan word. Die kern van sy opvatting oor die poësie is die belang van kommunikasie en vir hom lê daar 'n gesprek ten grondslag van elke gedig. Hy gee toe dat kommunikasie ' $n$ moeilike begrip is, omdat ' $n$ mens eintlik met die ander in jouself of met die veelvoud alter ego's in 
jouself praat en dus inderwaarheid in die eerste plek 'n gesprek na binne voer (Nolens, 2008).

Nolens se bundel Bres (2007) bestaan uit vyf reekse wat vroeër in aparte bundels gepubliseer is. In die "Verantwoording" (Nolens, 2007:103) agterin die bundel, staan dat Bres "tien jaar lang een dichtbundel in wording" was. Die digter verduidelik dat hy van die begin af geweet het dat die bepaalde reekse, wat al vyf aanvanklik in ander bundels verskyn het oor die tien jaar, uiteindelik in 'n groter geheel tereg sou kom. Die publikasies van elke reeks in 'n ander bundel was as 't ware die voorwerk of 'n onderdeel van 'n groter geheel. Die gedagte van ontwikkeling en uitdying is dus in die daadwerklike ontstaan van die bundel ' $n$ faktor, maar inhoudelik is die reekse in die bundel ook sterk verhalend, al is dit verkapte en onderbroke verhale, verhale wat vloei en stop en oormekaarskuif, om uiteindelik 'n komplekse beeld van 'n tydvak te gee.

'n Ander gedagte wat Nolens (2008) in die onderhoud beklemtoon, is dat daar uiteraard op ' $n$ manier altyd reeds ' $n$ narratief aanwesig is in iemand voordat hy/sy begin lees of praat of luister; 'n matriks of denkstruktuur of patroon (dus 'n skript in kognitiewe terme) wat waarskynlik narratief is en wat kommunikatiewe interaksie en reaksies bepaal. Niemand kom na 'n gedig as 'n tabula rasa nie - elke leesaksie is reeds by die aanblik van die eerste woorde 'n projeksie van iets wat vooraf gevorm is. Die leser konstrueer dus onvermydelik die verhaal wat agter die gedigte lê.

Daar is ook vir Nolens iets inherent narratief in taal as sodanig, want die denkstrukture word in taal vasgevang en bestaan in taal en bring ook taal tot stand sodat die verband tussen taal en denkstruktuur, ook die narratiewe denke, onlosmaaklik is (Nolens, 2008).

\subsection{Willem van Toorn}

Willem van Toorn (2007) sê onomwonde dat sy werk van die begin af gekenmerk is deur 'n voorliefde vir reekse en siklusse en dat hy nog altyd aangetrokke was tot die verhalende aspekte van die menslike bestaan en dit ook in sy poësie wil weergee.

Ik heb in mijn allervroegste gedichten zeker al reekse, altijd. Ik heb altijd al wel die vertellende kant en ik merk nu dat ik de laaste jaren eingenlijk steeds minder tevreden ben met het afzonderlijke, opzichzelfstaande gedicht ... Ik vind toch meer bevrediging in het gedicht dat ook die narratieve kant heeft, dat ook vertelt. En dat is ook riskant, omdat jij heel gauw in een soort parlando-achtige, gemakkelijk pratende poëzie belandt en 
dat wilt je natuurlik niet. Jij wilt dat het de kracht van poëzie houdt, maar door de samenhang die so een reeks kan geven, kunt je heel veel dingen binnenhalen in het gedicht, dat vind ik aantrekkelijk. (Van Toorn, 2007.)

In Van Toorn se oeuvre word bepaalde temas breed uitgewerk, omdat hy in siklusse en reekse 'n saak van verskillende kante benader. Die siklus "Het stuwmeer" (Van Toorn, 2004:37-52) is hiervan 'n goeie voorbeeld. 'n Insident, 'n ontmoeting met 'n vreemdeling, word deur die spreker in die gedigte beskryf en die figuur word dan die metafoor wat aanleiding gee tot 'n hele reeks ander kleiner verhale. Hierdie verhale bevat inhoude waarmee die digter aspekte van sy eie verlede herbesoek en probeer verwerk (vgl. Du Plooy, 2009:173198). Dieselfde werkwyse, hoewel meer tematies as verhalend, word gebruik in die reekse in De hofreis (2009), veral "La cittá ideale" en "Die Kunst der Fuge".

\subsection{Eva Gerlach}

Eva Gerlach se voorliefde vir samehangende bundels is bekend. Die boek De tweede gisting (Zuiderent \& Van der Starre, 2001), wat handel oor die samestelling van bundels, sluit af met 'n hoofstuk waarin Gerlach (2001:307-318) verslag doen oor die samestelling van die bundel Niets bestendiger (1998). Uit hierdie uiteensetting blyk dat volgorde en groepering vir haar baie belangrik is. Sy beskou die uitgesoekte gedigte en vind dan bepaalde tematiese aksente in die versameling, byvoorbeeld ten opsigte van ruimte, op-weg-wees, en diere. Sy oorweeg selfs die chronologie van ontstaan, 'n numeriese volgorde en die uiterlike vorm van die gedigte as potensiële ordeningsprinsipes. Uiteindelik besluit sy om die gedigte in vier reekse te groepeer en hoewel sy dink dat dit nie die enigste moontlikheid is nie, is dit wel die ordening wat haar op die bepaalde moment die beste bevredig:

$\mathrm{Nu}$ ik nog verkeer in de illusie dat er een Noodwendigheid zit in wat ik heb verzonnen, dat het niet onmiddellijk anders kan, niet verdwijnt als ik de ander kant uitkijk, geen vorm van bijgeloof is.

Dat het er is. (Gerlach, 2001:318.)

Vanweë die sorg wat sy aan bundelsamestelling bestee, was Gerlach dus 'n logiese keuse vir 'n gesprek oor narratiwiteit as 'n vorm van samehang in gedigtegroepe of enkelgedigte. In die onderhoud (Gerlach, 2007), wat hoofsaaklik gegaan het oor die bundel Situaties (2006), gee sy dan ook geredelik toe dat die verhalende wel in haar werk 'n rol speel: 
Ik denk in mijn eerste bundel, Verder geen leed, staan er al reeksen die eigenlijk ook steeds een soort vertellende structuur hebben, min of meer wel. (Gerlach, 2007.)

Dit gaan egter vir Gerlach baie beslis nie oor die verhalende as sodanig nie, dit is eerder asof die gedig of gedigte groei soos wat 'n idee ontwikkel:

Soms komt een gedicht op en je weet het is dat ene ding en soms denk je hier moet meer over, het is nog niet klaar ... En dan gaat het zich ontwikkelen en dan merkt je dat er een lijn in zit en dus, dan zit je feitelijk toch met een soort van verhaaltje met zijn eigen structuur. (Gerlach, 2007.)

Meestal is die verhaal in 'n gedig 'n klein verhaal of bloot 'n verhalende moment, maar dit is 'n kernmoment sodat die gedig nie in die anekdotiese verseil raak nie. Die onderskeid tussen verskillende soorte handeling in terme van die reikwydte van die effek van die handeling is hier ter sake. Hühn (2009:80) beskryf hierdie onderskeid tussen die twee soorte gebeurtenisse wat hy "event I" en "event II" noem. Hierdie onderskeid berus op die mate van spesifiekheid van die verandering wat so 'n gebeurtenis teweegbring. By "event I" vind daar 'n normale, patroonmatige en logiese verandering plaas in die teks, maar "event II" verwys na 'n gebeurtenis of handeling met beslissende of onvoorsiene en onafwendbare gevolge; dit veroorsaak 'n afwyking van normale verwagte gebeure en veranderings en is dus eie aan die verhaalverloop in die spesifieke teks. In Gerlach se gedigte is dit juis hierdie soort gebeurtenisse waaroor dit gaan; en dan word die verhaal 'n metafoor vir iets anders. Oor die verskil tussen die epiese en liriese, wat tradisioneel omskryf is as die representasie van 'n reeks gebeure in tyd en ruimte teenoor ' $n$ representasie van 'n momentele (liriese) ervaring, sê Gerlach:

'[H]et moment', dus niet alleen het lyrische moment, ook 'het moment in de tijd', wat is dat nu eigenlijk? Het is zo moeilijk, je kunt dat ook niet vastbinden. Je kunt er dus ook bijna niets over zeggen. Als dichter bent je om de een of andere reden toch steeds bezig met formuleren. Dit is iets wat mij al heel lang stoort. Omdat eigenlijk elk van mijn gedichten dat moment probeert te benaderen, dat centrale of mythische of hoe je dat moet noemen, kernmoment, ik weet niet hoe je dat moet uitdrukken ... En er zit zoveel omheen, dus schrijft je dan in een reeks, dan kunt je dat al meer alles bij elkaar laten komen en dan proberen of je op die manier dichter bij dat moment kunt 
komen. En daar gaat eigenlijk deze hele bundel over. 'Nu'. Wat is eigenlijk 'nu'? (Gerlach, 2007.)

Ironies genoeg lei haar strewe om die "nou" vas te vang en iets daaroor te sê haar daartoe om ter wille van die komplekse verhouding waarbinne elke oomblik "afspeel" of "gebeur", juis breër te kyk; en dit lei tot die verwoording van verhoudings en reeksmatigheid: "Ja, het volgt een lijn. Als je het zo navertelt, is dat niet waar het echt over gaat, maar het volgt die lijn." (Gerlach, 2007.)

Vir hierdie digter gaan dit meermale om die fassinasie wat sy vir 'n bepaalde personasie ontwikkel, soos byvoorbeeld in die siklus "Situaties" in die bundel Situaties (Gerlach, 2006:29-46) waar 'n figuur genaamd "l" met die afgesnyde kop van sy vrou op die mark en deur die strate van die stad loop. Die digter het die figuur, maar moet die verloop van die gebeure noodwendig volg en iewers tot 'n afsluiting bring:

$\mathrm{Ja}$, dat is dan ook een gegrepenheid die je dan hebt door degene waar het over gaat, de protagonist, en die kan je nog niet loslaten, want het is nog niet af; dus dat is ook iets wat bij het schrijven van een verhaal speelt, natuurlijk ... Ik moet in zo'n geval verder om de protagonist naar zijn bestemming te voeren, of zoiets, die ik ook nog niet weet. (Gerlach, 2007.)

Gerlach stel dit duidelik dat die kompleksiteit van die literêre formaat van gedigte met ' $n$ liriese aard en 'n gedeeltelik narratiewe inhoud, nie onderskat kan word nie. Die verhalende aspek van 'n gedig het 'n bepaalde ritme, dit berus op seleksie van baie spesifieke elemente uit 'n potensiële reeks verhalende gegewens. Gerlach gee ook toe dat liriese gedigte met sekondêre en selfs verskuilde verhalende aspekte werk, met kernmomente wat die ander verhaalgegewens weglaat om deur die leser veronderstel of verbeel te word. Meermale is die "verhaal in die gedig" onafgerond en oop, verwarrend, vaag en onverklaarbaar. Daar sit soms in so 'n verhaal "een gekte", want logika, samehang en sluiting of (erger nog) afgeslotenheid is hier nie relevant nie: dit is nie waarom dit gaan in 'n gedig nie. Die verhaal word metafoor van iets anders. Gerlach (2007) verduidelik dit soos volg:

Ik heb het heel lang als een zwakte van mijzelf gezien, want ik wilde eigenlijk verhalen schrijven, maar iedere keer werd het toch weer een gedicht. Ik heb ook echt geprobeerd om dat uit te bannen en lyrische gedichten te schrijven. Ja, en op een gegeven moment kwam er een soort mengvorm tot stand, waarbij, als je het als een verhaal leest, is het niet een erg 
duidelijk of helder verhaal. En als je het als een metafoor leest, is het ook geen heldere metafoor, denk ik. En als je het als poëzie leest, is het ook geen heldere poëzie.

Wat egter wel vir Gerlach ononderhandelbaar is, is die belang van die poëtiese vorm wat uiteindelik in die gedig tot stand kom:

De vorm en de inhoud [...] zijn een geheel en dragen samen over waar het gedicht op uit is ... Waar het mij eigenlijk in deze hele bundel om gaat, is ... poëzie, grote lyrische poëzie, is voor mij een moment. Het moment dat ineens naar boven komt en geweldige kracht krijgt en een soort licht gaat geven. Dat is wat voor mij in ieder groot gedicht ... de klap op je hart geeft. (Gerlach, 2007.)

Sy gebruik 'n mooi beeld om die ontwikkeling van 'n gedig te illustreer: "Ik heb het gevoel dat een gedicht ... echt net als een kind is dat moet groeien, het moet gewoon zijn ding doen en dan gebruikt het jou ... om dat te doen." (Gerlach, 2007.)

\section{Situaties (2006) en "Pad tussenbeide"}

In Gerlach se bundel Situaties (2006) is daar nege afdelings. Die bundel as geheel word byeengehou deur die tematiek van herinnering en die onmoontlikheid om in herinnerings die volheid van belewenis weer op te roep of vas te vang. Alles is in proses en op weg en die sprekers in die gedigte bevind hulself dikwels in tussenruimtes en tussenfases, omdat bestemmings en vastighede slegs teoreties bestaan. Dit is hierdie "tussensituaties" wat in die verse opgeroep word.

Die hele bundel word nie hier bespreek nie, maar die siklus "Pad tussenbeide" (Gerlach, 2006:11-15) word ontleed as voorbeeld van 'n verhalende siklus waarvan die betekenis veel meer is as die verhaal op sigself.

In hierdie siklus in die eerste afdeling van Situaties (Gerlach, 2006) gaan dit oor 'n erg beseerde en sterwende padda wat deur die spreker opgetel word, "met grond en al". Die padda word aangespreek en 'n klein verhaal ontwikkel: Die spreker wil die padda daarvan bewaar om 'n onverwagte en onwaardige dood te sterf. Sy identifiseer met die magtelose dier en ruil rolle om met die padda. Waar sy eers vir die padda sê: "Red je", word dit aan die einde van die eerste gedig: "Ik red me". Daarna staan die padda op en dans terug in die lewe in, losser en meer onbevange as wat van hom verwag word. Hy "verpletter auto's" en bevrug die wyfie se stringe eiers. Die padda 
kan in hierdie geleende tussentyd 'n hele lewe voer. Eers daarna (in die vierde gedig) gee hy sy doodskreeu en moet hy ten dode opgedra word deur die verhale van sy lewe op te dis. Uiteindelik is dit die spreker in die gedig wat die dooie padda "opruim", maar sy weet dat sy hom nie maklik kan aflê ("loslaten") nie, hom nie ligtelik kan vrylaat om hom na sy verlossende dood te haas nie.

Daar is dus 'n besliste verhaallyn in die siklus. Daar is 'n padda en 'n "ek"-spreker in die gedig as personasies, daar is 'n plek van gebeure asook 'n tydsverloop wat in opeenvolgende teksgedeeltes gerepresenteer word. Dit is egter nie waarom die reeks gaan nie. Uit die liriese en emosionele verwoording blyk dat dit inderwaarheid gaan om die bykans onuitstaanbare deernis met die gewonde padda en die weiering om die dier toe te laat om so sonder seremonie te sterf. Die verhaaltjie hou die vlietende en uitwaaierende gedagtes wat in die verse ter sprake kom, bymekaar, terwyl die intensiteit van die emosie uitgebeeld word in die elliptiese sinne en die intense metafore van die poëtiese aanbod. In die eerste vers (Gerlach, 2006:11) ruil die rolle om en die spreker in die gedig verset haar in die plek van die padda, namens die padda, teen die troostelose en toevallige dood: "Wees mij, laat in je hand mij / leeglopen!" Sy word 'n soort redder wat staan tussen die padda en die "niks namaals".

In die tweede gedig (Gerlach, 2006:12) word 'n verdere lewe vir die padda verbeel, asof daarmee vir die padda 'n identiteit gebou kan word, ' $n$ identiteit van meer krag en selfverweer. So word hy Padda met 'n hoofletter; nie hierdie enkele versukkelde halfdooie padda nie, maar 'n uitnemender en 'n spesifieke eksemplaar van sy soort met 'n eienaam, selfversekerd en sterk. Dit gebeur deur die mediëring van die ek-spreker of verteller in die gedig, deur middel van die digter, deur middel van die gedig. Die intensiteit van die identifisering met die padda representeer ' $n$ intense behoefte om deur hierdie dier vir alle verdruktes en sterwendes, vir ongekende en onbenullige slagoffers 'n nuwe lewe te verbeel, sodat hulle bestaan geldiger kan wees.

In die tydsgleuf tussen die ontdekking van die gewonde dier en sy daadwerklike sterwe, in hierdie tussensituasie, word Padda terugwerkend met waardigheid toebedeel. Dan sterf "Pad Scheurkeel" met 'n gekrys. Hy kry hier 'n naam met twee hoofletters en sy doodskreet het 'n geweldige uitwerking op die "ek" in die verse:

Trekt

zich doormidden, lucht zo ver uit elkaar

dat met een donderklap je hart blijft staan 
terwijl zijn krijs wegloopt en alles weer

rommelt of niks. (Gerlach, 2006:14.)

Tog word die intensiteit weer gerelativeer as gesê word: "Geen veer gevallen, geen haar gekrenkt want hij heeft geen van twee." In dieselfde relativerende trant word gestel: "Naast alles ligt alles." (Gerlach, 2006:14-15.)

Uiteindelik weet die spreker in die gedig: Die dier moet "kruip in mijn bloed", omdat hy deel is van die voortgaande proses van lewe en dood. Die dood kan nooit maklik aanvaar word nie en lewende wesens kan nie maklik losgelaat word nie. Die gedig sluit af met die gedagte dat daar nie na die dood toe gehaas moet word nie. Onderliggend aan die verhaal lê die nadenke oor wat lewe is. Is daar net die oomblik van lewe, die hier en die nou? Is daar iets anders wat vir die sterwende voorlê? Kan die dood vanuit die lewe getransendeer word? Die verhaal van die verwonde en sterwende padda word die vehicle waardeur vrae oor waardigheid, oor die betekenis van bestaan, oor lewe en dood aan die orde gestel word.

Wat 'n mens nou vind in die gedigte is dat die intense en beswerende karakter van die woordgebruik, die metaforiek en die gebroke sintaksis gebind word deur die onderliggende verhaalmomente. Dit is duidelik 'n gefragmenteerde verhaal wat bestaan uit enkele momente van verandering, maar hierdie gebeurtenisse wat die verandering bring, is van groot betekenis. Die gedig gee eintlik verslag van 'n verbeelde verloop van gebeure, maar die verwonding en die omkering van die verwonding wat in die gedig verhaalmatig ontgin word, is juis die duidelikste aanduiding van die verskuiwing weg van 'n gebeurtenis as sodanig na die poëtiese betekenis van die (verbeelde) gebeure. Die verbeelde verhaal word metafoor van die spreker in die gedig se letterlike meelewing met die sterwende dier ten einde iets van lewe en dood en wat daarop sou kon volg (die "niks namaals"), te begryp. Dit gaan nie net om die padda se dood nie, maar om die dood as sodanig; oor die betekenis van lewe en dood en die betekenis van die kwaliteit van lewe en dood. Die reeks put dus seggingskrag uit sowel die poëtiese middele as die verhalende onderbou.

\section{Gevolgtrekking}

Hoewel 'n narratiewe benadering nie vir alle liriese gedigte geskik is nie, bied dit wel 'n nuwe invalshoek tot gedigte om op hierdie manier te lees, veral aangesien daar wel tans soveel enkelgedigte, gedig- 
reekse en siklusse bestaan wat vra om 'n verrekening van die narratiewe inhoud daarvan.

Een aspek wat myns insiens noodwendig aan die orde kom, is die vraag of digters hierdie werkwyse bewus of onbewus volg. Uit die onderhoude blyk dat daar tegelyk iets onbewus en iets bewus in die digterlike proses werksaam is. Die digters herken en erken almal dat die narratiewe inhoud of struktuur 'n rol in hulle werk speel, maar dit word met digterlike vakmanskap hanteer. Die idee, of dit nou 'n kern van woorde of 'n tema is, word gevolg. Indien daar 'n lyn ontwikkel, moet dit gevolg word en tot 'n poëties bevredigende slot gevoer word. Die verhalende is nie dominant nie, want dit gaan by nie een van die digters om die soeke na 'n logies verhalende afloop of ' $n$ bevredigende verhaalafsluiting nie, maar juis om 'n poëtiese verkenning van die onderwerp of tema.

Die optimale ontginning van 'n onderwerp is die aanleiding waaruit die gedig of die gedigtegroep groei, en wat ook al daarvoor nodig is, moet gebruik word. Die hibridisering van vorms, van denkmodusse en genre-eienskappe staan sekondêr tot die noodwendigheid van die tematiese ontwikkeling, sodat narratiewe en poëtiese middels vrylik gebruik en vermeng word in die proses waaruit die gedig groei. In aansluiting hierby word met bekende inhoude en temas en bekende verhaalvorms gewerk, maar die ondermynende, die alternatiewe en aweregse kry voorrang. Watter vorms of tegnieke gebruik word, staan ten dienste aan vervreemding, want die poësie is en bly ' $n$ spel met die bekende en onbekende, met herhaling en vernuwing en verandering.

Wat wel duidelik geword het uit die bestudering van die stof wat uit die onderhoude met die digters na vore gekom het, is dat die aanvoeling dat narratiewe inhoude in liriese poësie werksaam is en selfs belangrik is, geregverdig is. ' $n$ Benadering wat juis op hierdie narratiewe aspekte van liriese poësie fokus, of 'n benadering wat narratologiese konsepte gebruik om ongewone aspekte van gedigte te ontleed, blyk dus duidelik geldig en vrugbaar te wees.

\section{Geraadpleegde bronne}

ABBOTT, H.P. 2009. Narrativity. (In Hühn, P., Pier, J., Schmid, W. \& Schönert, J., eds. Handbook of narratology. Berlin: De Gruyter. p. 309-328.)

ANKER, R. 1989. Goede manieren: een episodich gedicht. Amsterdam: Querido.

ANKER, R. 2002. De Broekbewapperde mens. Amsterdam: Querido. 
ANKER, R. 2007. Transkripsie van onderhoud met Robert Anker. Opgeneem te Amsterdam, 24 Nov. 2007. (Onderhoud gevoer met Heilna du Plooy en Bernard Odendaal.)

BAMBERG, 2009. Identity and narration. (In Hühn, P., Pier, J., Schmid, W. \& Schönert, J., eds. Handbook of narratology. Berlin: De Gruyter. p. 132142.)

BRONZWAER, W. 1993. Lessen in lyriek: nieuwe Nederlandse poëtica. Nijmegen: Sun.

DU PLOOY, H. 1986. Verhaalteorie in die twintigste eeu. Durban: Butterworth.

DU PLOOY, H. 2006. H.J. Pieterse. (In Van Coller, H.P., red. Perspektief en profiel. DI. 3. Pretoria: Van Schaik. p. 409-427.)

DU PLOOY, H. 2009. Die verhale in en om verse, met spesifieke verwysing na "Het stuwmeer" van Willem van Toorn. (In Foster, R., T'Sjoen, Y. \& Vaessens, T., reds. Over grenzen/Oor grense: een vergelijkende studie van Nederlandse, Vlaamse en Afrikaanse poëzie/'n vergelykende studie van Nederlandse, Vlaamse en Afrikaanse poësie. Leuven: Acco. p.173198.)

DU PLOOY, H. 2010. Veelvlakkig vertel: narratiewe strukture en tegnieke in Kleur kom nooit alleen nie van Antjie Krog. Stilet, 22(3):36-62.

DUBROW, H. 2006. The interplay of narrative and lyric: competition, cooperation, and the case of the anticipatory amalgam. Narrative, 14(3):254271.

FEIRSTEIN, F. 1998. Rhyme. (In McDowell, R., ed. Poetry after modernism. Brownsville: Story Line. p. 255-267.)

GERLACH, E. 2001. Over het ordenen van gedichten in een bundel: Niets bestendiger (een reconstructie). (In Zuiderent, A. \& Van der Starre, E., reds. De tweede gisting: over de compositie van dichtbundels. Amsterdam: Amsterdam University Press. p. 307-320.)

GERLACH, E. 2006. Situaties. Amsterdam: De Arbeiderspers.

GERLACH, E. 2007. Transkripsie van onderhoud met Eva Gerlach (Margaret Dijkstra). Opgeneem te Amsterdam 23 Nov. 2007. (Onderhoud gevoer met Heilna du Plooy en Bernard Odendaal.)

HÜHN, P. 2005. Transgeneric narratology: application to lyric poetry. (In Pier, J., ed. The dynamics of narrative form: studies in Anglo-American narratology. Berlin: De Gruyter. p. 139-158.)

HÜHN, P. 2009. Event and eventfulness. (In Hühn, P., Pier, J., Schmid, W. \& Schönert, J., eds. Handbook of narratology. Berlin: De Gruyter. p. 80-97.)

HÜHN, P. \& KIEFER, J., eds. 2005. The narratological analysis of lyric poetry: studies in English poetry from the 16th to the 20th century. Berlin: De Gruyter.

HÜHN, P. \& SOMMER, R. 2009. Narration in poetry and drama. (In Hühn, P., Pier, J., Schmid, W. \& Schönert, J., eds. Handbook of narratology. Berlin: De Gruyter. p. 228-241.)

$\mathrm{KAHL}, \mathrm{H}$. 2010. A narratological perspective on Douglas Livingstone's A littoral zone (1991). Literator, 31(3):181-199.

KROG, A. 1989. Lady Anne. Bramley: Taurus.

KROG, A. 2000. Kleur kom nooit alleen nie. Kaapstad: Kwela Boeke.

LIESKE, T. 2002. Stripping \& andere sterke verhalen. Amsterdam: Querido.

LIESKE, T. 2007. Transkripsie van onderhoud met Tomas Lieske (Ton van Drunen). Opgeneem te Leiden, 21 November 2007. (Onderhoud gevoer met Heilna du Plooy en Bernard Odendaal.) 
LIND, M. 1998. On epic. (In McDowell, R., ed. Poetry after modernism. Brownsville: Story Line. p. 323-361.)

LIVINGSTONE, D. 1991. A littoral zone. Pietermaritzburg: The Carrefour Press.

LOTMAN, J. 1977. The structure of the artistic text. Trans. by G. Lenhoff \& R. Vroon. Michigan: Ann Arbor.

MARAIS, D. 2010. Effe onmusikale worshonde, oftewel die poësie in die raamwerk van die verhalende vers. Stilet, 22(3):124-143.

MCHALE, B. 2009. Beginning to think about narrative in poetry. Narrative, 17(1):1-26, Jan.

MORGAN. M.R. 2008. Narrative means to lyric ends in Wordsworth's Prelude. Narrative, 16(3):298-330.

NAUDÉ, C.P. 2010. Slegs aanskyn: vertelling as tegniek in die liriese vers. Stilet, 22(3):11-123.

NOLENS, L. 2007. Bres. Amsterdam: Querido.

NOLENS, L. 2008. Transkripsie van onderhoud met Leonard Nolens. Opgeneem te Antwerpen, 22 Oktober 2008. (Onderhoud gevoer met Heilna du Plooy.)

OPPERMAN, D.J. 1979. Komas uit 'n bamboesstok. Kaapstad: Tafelberg.

PHELAN, J. 2005. Spreading the word(s). Narrative, 13(2):85-89.

PHELAN, J. 2009. The narrative turn and the how of narrative inquiry. Narrative, 17(1):1-10.

PIETERSE, H.J. 2000. Die burg van hertog Bloubaard. Kaapstad: Tafelberg.

SORENSEN EMERY-PECK, J. 2008. Tom and Vivien Eliot do narrative in different voices: mixing genres in The waste land's pub. Narrative, 16(3):331-358.

TOOLAN, M. 2009. Coherence. (In Hühn, P., Pier, J., Schmid W. \& Schönert, J., eds. Handbook of narratology. Berlin: De Gruyter. p. 44-62.)

VAN DER STARRE, E. 2001. Eenheid en volgorde. (In Zuiderent, A. \& Van der Starre, E., reds. De tweede gisting: over de compositie van dichtbundels. Amsterdam: Amsterdam University Press. p. 29-46.)

VAN TOORN, W. 2004. Het stuwmeer. Amsterdam: Querido.

VAN TOORN, W. 2007. Transkripsie van onderhoud met Willem van Toorn. Opgeneem te Amsterdam, 27 November 2007. (Onderhoud gevoer met Heilna du Plooy en Bernard Odendaal.)

VAN TOORN, W. 2009. De hofreis. Amsterdam: Querido.

WILLOCKX, D. 2010. Poëtische avonturen: over de verhouding tussen narratieve structuren en poëtische aspecten in twee lange gedichten. Literator, 31(3):123-138.

ZUIDERENT, A. \& VAN DER STARRE, E., reds. 2001. De tweede gisting: over de compositie van dichtbundels. Amsterdam: Amsterdam University Press. 


\section{Kernbegrippe:}

Anker, Robert

Gerlach, Eva

Lieske, Tomas

liriese poësie

narratiwiteit

narratologiese benadering tot poësie

Nolens, Leonard

Van Toorn, Willem

\section{Key concepts:}

Anker, Robert

Gerlach, Eva

Lieske, Tomas

lyrical poetry

narrativity

narratological approach to poetry

Nolens, Leonard

Van Toorn, Willem 